\title{
QUALITY-OF-LIFE EXPERIENCES FROM THE PERSPECTIVE OF PATIENTS RECEIVING HAEMODIALYSIS FOR CHRONIC RENAL FAILURE
}

Author:

Louis F. Small ${ }^{1}$

\author{
Affiliation: \\ ${ }^{1}$ Department of Nursing, \\ University of Namibia, \\ Namibia
}

\section{Correspondence to:}

Louis Small

email:

lsmall@unam.na

Postal address:

PO Box 86002, Eros,

Windhoek 9000, Namibia

Keywords:

chronic renal

failure; experiences;

haemodialysis; perspective

of patients; quality of life

Dates:

Received: 19 Nov. 2009

Accepted: 12 July 2010

Published: 29 Nov. 2010

How to cite this article: Small, L.F., 2010, 'Qualityof-life experiences from the perspective of patients receiving haemodialysis for chronic renal failure', Health SA Gesondheid 15(1), Art. \#521, 7 pages. DOI: 10.4102/hsag.v15i1.521

This article is available at: http:/ / www.hsag.co.za

(C) 2010. The Authors. Licensee: OpenJournals Publishing. This work is licensed under the Creative Commons Attribution License.

\section{ABSTRACT}

This study describes the experiences of patients receiving haemodialysis for chronic renal failure at the only dialysis centre in Windhoek, Namibia. A qualitative, explorative and descriptive design was used. Data were collected by means of in-depth interviews and analysed using Tesch's process. Four themes emerged from the data, relating to (1) financial constraints, (2) loss of independence and spontaneous activities, (3) strain on relationships and (4) feelings of significant physiological changes and weakness. Based on the results, recommendations were submitted for psychosocial support and the establishment of support groups.

\section{OPSOMMING}

Hierdie studie beskryf die ervarings van pasiënte wat gehemodialiseer word vir chroniese nierversaking in die enigste dialise-eenheid in Windhoek. 'n Kwalitatiewe, verkennende en beskrywende studie is gedoen. Die data is deur middel van diepte-onderhoude ingesamel, waarna die data aan die hand van Tesch se metode geanaliseer is. Daar het vier temas uit die studie na vore gekom (1) finansiële beperkings, (2) verlies van onafhanklikheid en spontane aktiwiteite, (3) druk in verhoudings en (4) gewaarwordings van beduidende fisiologiese veranderinge en swakheid. $\mathrm{Na}$ aanleiding van hierdie bevindings is die daarstel van psigososiale ondersteuning asook ondersteuningsgroepe aanbeveel.

\section{INTRODUCTION}

\section{Background}

Any type of chronic health problem requires lifestyle changes and adaptations by the sufferer, usually for the remainder of the person's life. An individual in end-stage renal failure, if not immediately able to receive a donor kidney, then also becomes afflicted with a chronic condition. In such cases, the lifestyle changes and adaptations become a considerable undertaking.

With chronic renal failure (also known as chronic kidney disease) there is a build-up of metabolic waste products, which, if not removed, could lead to a severe decline in health and certain death eventually. In Namibia, the options available to these patients are essentially threefold (1) a kidney transplant, (2) peritoneal dialysis or (3) haemodialysis. As this study focuses on the experiences of patients receiving haemodialysis, no further reference will be made to kidney transplants or peritoneal dialysis. Currently, haemodialysis is only available for patients with their own funds or medical funds. Furthermore, it might be necessary for them to relocate to one of only three cities or towns that offer this treatment: Windhoek, Walvis Bay or Ongwedhiwa. During 2009, there were 32 patients who required, and could afford, haemodialysis for chronic renal failure in Namibia (N. Brandt pers. comm., 2010). Reliable information is not available on the number of patients unable to afford treatment because of a lack of funds, but a comparison could be made with the Western Cape in South Africa. This province, with a population of just over three million people, has on average 1000 patients per year that require haemodialysis, but who are unable to afford it (The Southern Times 2008). In comparison, Namibia has a population of just over two million, and since it is also a developing country, the assumption could be made that a few hundred patients per year would require haemodialysis.

Haemodialysis is a process that is used to treat patients with chronic renal failure, whereby the waste products of metabolism and accumulated fluids are removed (Marieb \& Hoehn 2007:1023). This therapeutic process usually requires patients to visit a designated renal dialysis unit three times a week for about $4 \mathrm{~h}$ per visit or session, thus averaging about $12 \mathrm{~h}$ per week on dialysis treatment. The treatment is invasive in nature, where specialised needles are inserted into the patients' vascular system and their blood is redirected through a machine, which removes the metabolic waste products and the accumulated fluid by means of filtration, osmosis and diffusion (Urden, Stacy \& Lough 2006:828-829). The invasiveness of this process in itself has the potential for complications such as shock and other reactions.

Apart from the possible complications and the long periods of time spent on the dialysis machine, there are other aspects that have the potential to disrupt a patient's life. The loss of kidney function results in significant lifestyle changes and adaptations by the patient. Firstly, the body is no longer able to dispose of fluids effectively. As no, or very little urine is produced, oedema develops and fluid intake therefore has to be restricted. In addition, certain metabolic waste products, such as the waste products of protein metabolism, are also excreted through the kidneys; thus any kidney malfunction would automatically lead to an increase in these waste products, with the accompanying disorders caused by their accumulation. The solution is therefore to restrict protein intake, in itself a considerable lifestyle adaptation (Copstead \& Banasik 2005:743-745).

These changes and the adaptations that have to be made to accommodate them affect the patients' quality of life, the magnitude of which is difficult to measure. The boundaries of definition for quality of 
life usually depend on why one is assessing health, as well as on the particular concerns of patients, clinicians and researchers. A viewpoint that is often encountered from a medical perspective is expressed as follows: 'Although low or unstable income, the lack of freedom, or a low-quality environment may adversely affect health, these problems are often distant from a health or medical concern' (Guyatt, Feeny \& Patrick 1993:622). Therefore, the research instruments used by many medical practitioners tend to focus on measurable variables, such as those that relate to physical attributes, and the closeness of a return to preillness strength and physical abilities. In situations of chronic renal failure, many of these variables are known, although the magnitude and extent for individual patients might not be known.

Further aspects that are unknown are other, less quantifiable components of what is regarded as an acceptable quality of life. This is particularly relevant if the definition of health-related quality of life (HRQL), as described by Guyatt et al. (1993:622), is considered: HRQL includes income, freedom and the quality of the environment. The notion of quantifiable instruments is shared by Maxwell and Fitzpatrick (1998:182), who opine that these measures (instruments) of health generally struggle to capture the ways in which patients with renal failure accept considerable limitations in their HRQL, in return for the prospect of further life.

\section{PROBLEM STATEMENT}

At the Windhoek dialysis unit, one of the problems experienced when planning and caring for patients with chronic renal failure was a lack of knowledge of the aspects of patients' experiences that are not easily accessible using quantitative studies, but which also form part of their perceptions of an acceptable quality of life. The rationale for seeking to uncover this information was that this knowledge is necessary to provide professional support that takes into consideration a person's whole life situation (Hagren et al. 2005).

\section{PURPOSE OF THE STUDY}

The purpose of this study was to describe the experiences of patients receiving haemodialysis for chronic renal failure at the only dialysis centre in Windhoek. This information could assist in providing any necessary support and could provide the primary care provider, the registered nurse in this study, with additional information on how best to plan and care for these patients.

\section{Concept definitions \\ Chronic renal failure}

Chronic kidney failure is defined as either kidney damage, or a decreased kidney glomerular filtration rate of less than $60 \mathrm{~mL} /$ minute $/ 1.73 \mathrm{~m}^{2}$ for three or more months. Whatever the underlying aetiology, the destruction of renal mass with irreversible sclerosis and loss of nephrons leads to a progressive decline in the glomerular filtration rate (Verrelli 2008:1). Chronic renal failure is also known as chronic renal disease.

\section{Quality of life}

Quality of life is the degree of well-being felt by an individual or group of people. Unlike standard of living, quality of life is not a tangible concept and therefore cannot be measured directly; it is personal and value-laden. Quality of life has the dual dimensions of objectivity and subjectivity: objectivity examines the person's ability to function, whereas subjectivity analyses their psychosocial state (Urden et al. 2006:16)

Another definition of quality of life is provided by Johnson and Maas (1997:239), who see it as an individual's expressed satisfaction with current life circumstances. Some of the indicators that they have identified are satisfaction with health status, social status, environmental status, economic status, education level, close relationships and coping ability.

\section{RESEARCH METHOD AND DESIGN}

The approach adopted in this study was qualitative, explorative and descriptive. In qualitative research, the focus is on the participants' experiences from their own perspective (De Vos et al. 2003:268), an aspect that was implemented in this study. The research undertaken in the study is regarded as explorative, since little is known about the quality of life of patients with chronic renal failure in Namibia, and an analysis and description was required.

\section{Research setting}

The study was conducted in the only haemodialysis facility in Windhoek and one of only three in Namibia. This facility can accommodate 12 patients at a time and employs a medical specialist, five registered nurses and a clinical technologist amongst its personnel.

\section{Population and sampling}

The population comprised all the patients (participants) on renal replacement therapy (haemodialysis) in the dialysis unit during the period January to February 2009. An accessible population of 25 people was available for the study, the youngest being in his early twenties and the eldest just over 70 years of age. The division between male and female was approximately equal. No sampling was done, and all the patients who were willing were included in the study: 21 patients agreed to be interviewed.

\section{Pilot study}

A pilot study was conducted by interviewing two patients from the same population that was used in the main study to test the clarity of the question(s). These two participants were excluded from the main study, as the clarity of the recordings of their narratives was sub-optimum.

\section{Data collection}

All of the patient interviews were conducted by the researcher and were tape-recorded and transcribed verbatim. The participants were interviewed while receiving treatment and all the treatment areas were private, with only occasional interruptions by registered nurses to collect data on the functioning of the dialysis machines. Follow-up sessions for ensuring the trustworthiness of the data were conducted three months after the initial interviews. Approximately half of the interviews were conducted in Afrikaans, but, as the researcher is fluent in Afrikaans, no translation was required for the data analysis.

All participants were asked a central question:

'How do you experience your quality of life since being diagnosed with chronic renal failure?'

To enhance the richness of the data, the researcher employed specific interviewing techniques, including paraphrasing and reflecting on the questions that were asked.

Field notes were also taken during the interviews, which were mainly observational, theoretical and personal. The observational notes were descriptive and concentrated on the factual details of the interview situation, while the theoretica notes attempted to derive meaning from the observational notes. The personal notes were descriptions of the researcher's own reflections, reactions and experiences (Wilson 1989:436-443).

\section{Data analysis}

Data was analysed according to Tesch's method (as cited in Creswell 1998:190-195), which consists of eight steps, focusing the researcher on a logical approach. This entailed reading all the transcripts, then selecting one (the shortest or most interesting) 
and after this initial analysis, the remaining transcripts were examined in a similar fashion. The topics that emerged were listed and clustered together. Codes were assigned to the topics and these were then converted into themes using descriptive words.

An independent coder assisted in this activity and also helped the researcher to decide on the themes and patterns identified.

\section{ETHICAL CONSIDERATIONS}

Permission to conduct the study was obtained from Professor O.J. Oosthuizen, specialist physician and manager of the dialysis unit in Windhoek. Written, informed consent was obtained from the participants, all of whom had been diagnosed with chronic renal failure.

The proposal for this study was also approved by the research committee of the Faculty of Medical and Health Sciences at the University of Namibia.

\section{TRUSTWORTHINESS}

Guba's model, as cited in Krefting (1991:214-222), was used to ensure trustworthiness. This model is well developed conceptually and has been used extensively by qualitative researchers, particularly nurses and educators (Krefting 1991:215).

The following four criteria for ensuring trustworthiness were applied (1) truth value, (2) applicability, (3) consistency and (4) neutrality. Applying certain strategies for credibility ensured the truth values, and the application of strategies for transferability ensured applicability. To ensure consistency, strategies of dependability were applied and, for neutrality, strategies of confirmability were applied.

Table 1 provides a schematic presentation of how trustworthiness was ensured in the study.

\section{DISCUSSION AND RESULTS}

Four themes and 10 patterns emerged from the data analysis, which are shown in Table 2.

\section{Financial constraints}

The process of dialysis is expensive. Currently, dialysis facilities in Namibia are only available for patients who are able to pay or who belong to a medical fund and thus, patients without the necessary funds or a medical aid find themselves in a dire situation.

Even participants with medical funds, as is the case with most of the participants, might experience financial constraints. These financial constraints could be grouped into the following patterns:

- medication and treatment expenses

- transport expenses, and

- salary implications.

These patterns had the potential to decrease the quality of the patients' health, as it appeared that, during periods of financial crisis, the patients tended to cut down on some of the expense categories that are described here. The first such expense to be curtailed related to medication and treatment.

\section{Medication and treatment expenses}

Out-of-pocket expenses are the chief reason for patients reducing their adherence to medication (Hirth 2009:1). Hirth (2009) et al. surveyed patients undergoing kidney dialysis in the United States of America (USA), Canada, Australia, New Zealand, Japan and several Western European nations, and found that the proportion of American patients who said they did not purchase medication because of cost significantly exceeded that of any other country. However, most of the other countries also showed an increased risk of non-adherence associated with higher cost pressures.

Similar experiences were observed in this study. When some of the participants encountered periods of limited funds they

TABLE

A schematic presentation of the strategies for establishing trustworthiness together with their criteria and implementation in the study

\begin{tabular}{|c|c|c|}
\hline Strategy & Criteria & Implementation \\
\hline Truth value (credibility) & Prolonged engagement & - Time was allowed to become acquainted and to form a trusting relationship with participants. \\
\hline- & Reflexivity & $\begin{array}{l}\text { - Field notes were taken. } \\
\text { - Researcher participated in the research and was not just be an observer. }\end{array}$ \\
\hline - & Time sampling & $\begin{array}{l}\text { The interviews were preceded by a unrecorded settling-down time during which the nature and purpose of the study } \\
\text { was explained. } \\
\text { - A couple of months were needed to prepare for this research. } \\
\text { A pilot study was conducted. }\end{array}$ \\
\hline - & Member checking & $\begin{array}{l}\text { The participants were involved to ensure the research findings are a true reflection of their experiences. } \\
\text { - Follow-up interviews were conducted to clarify themes in the data collected. }\end{array}$ \\
\hline - & Peer examination & - An independent coder was used. \\
\hline Applicability & Dense description & $\begin{array}{l}\text { - A demographic description of the participants was done. } \\
\text { - Rich descriptions of findings were done. }\end{array}$ \\
\hline Consistency & Dense description & $\begin{array}{l}\text { - A full description of the data collection and data analysis methods was provided in order for other researchers to trace } \\
\text { the methods used. }\end{array}$ \\
\hline Confirmability & Audit trail and audit process & $\begin{array}{l}\text { - The research committee of the Faculty of Medical and Health Sciences assessed the proposal and research process. } \\
\text { - An audit trail was maintained by keeping personal notes and field notes. }\end{array}$ \\
\hline - & Reflexivity & - As discussed under truth value. \\
\hline
\end{tabular}

TABLE 2

Patterns and themes that emerged from the data

\begin{tabular}{|c|c|c|}
\hline Number & Theme & Patterns \\
\hline 1 & Experiences of financial constraint & $\begin{array}{l}\text { - Medication and treatment expenses } \\
\text { - Transport expenses } \\
\text { - Salary implications }\end{array}$ \\
\hline 2 & Experiences of loss of independence and spontaneous activities & $\begin{array}{l}\text { - Confinement to the city of Windhoek } \\
\text { - Long periods confined to the dialysis machine }\end{array}$ \\
\hline 3 & Experiences of strain on relationships & $\begin{array}{l}\text { - Altered family dynamics } \\
\text { - Changed dynamics in social relations with friends } \\
\text { - Work-related stress }\end{array}$ \\
\hline 4 & Experiences of feelings of significant physiological changes and weakness & $\begin{array}{l}\text { - Dramatic physiological changes } \\
\text { - Experiences of weakness }\end{array}$ \\
\hline
\end{tabular}


cut back on certain items like medication, as evidenced by this participant's remark:

\section{'Sometimes I delay in acquiring my medication'.}

Many of the participants commented on the $5 \%$ that they had to pay, as most medical aid funds will only contribute $95 \%$ of the total costs. During 2009, the 5\% would have amounted to N\$150 per dialysis session and, as nearly all the participants were dialysed three times a week, the total expenditure per week amounted to $\mathrm{N} \$ 450$ (1 $\mathrm{N} \$$ is equivalent to 1ZAR).

A participant expressed the following

'I have stayed away because I did not have the N\$150 to pay for each dialysis'.

Even if the participants did not have to resort to such drastic action as curtailing their medication or dialysis treatment, they still experienced the effects of the hidden costs of dialysis. One such hidden cost lies in the specific dietary requirements that have to be complied with, which necessitate the buying of special food groups that are more costly than the standard diet items of the patients. This fact is acknowledged by the Fresenius Medical Care Group, which states in its nutritional guidelines that some patients might not be able to afford better quality food (Fresenius Medical Care South Africa 2008). A participant made the following remark in this regard:

$$
\text { '... it is not good for my pocket - it is nearly finished'. }
$$

\section{Transport expenses}

A participant described expenditure on taxis as follows:

'... now, if they have to bring me here, then they ask as much as $R 50$, or R70, R80. It all depends'.

These costs are only for one-way trips, and as this patient had to be dialysed three times a week, travelling expenses amounted to between N\$1600 and N\$1900 per month. Many participants rely on taxis as a means of transport.

In Iran, full medical insurance coverage is available to all patients with chronic renal failure, but transport expenses must be paid directly by these patients. Thus, their main expenditure lies in transport costs (Arefzadeh, Lessanpezeshki \& Seifi 2009:307311).

\section{Salary implications}

Added to the financial constraints experienced by the participants are the uncertainties and problems encountered at their workplaces. One participant in private business had this to say: 'My business slowed down ...', an element that could be attributed to the many hours per week required for dialysis. For those fortunate enough to still be employed, changes had also occurred in their financial status. The following quote best supports this:

'But you see, the hours that I sit here, they subtract [sic]. That is a big change in my life. And, they take a large amount for the whole month. So, that is a big change that I have seen in my life'.

Another aspect of finance-related strain is that the possibility of earning extra money is sometimes also limited. One participant said:

'I have used to work overtime, but I can no longer do so'.

Ko, Lee and Shih (2007:53-61) maintain that patients with chronic renal failure tend to find fewer work opportunities, which might also result in financial constraints.

Employment implications, and thus implications in salary, are noted more widely in previous studies. In the USA, a study established that approximately $42 \%$ of patients with chronic renal failure were employed full time before beginning dialysis; only $21 \%$ were employed when they began dialysis, and only $13 \%$ were employed a year later. Those patients who continued working while on dialysis (49\%) were most likely to be professional and/or white collar workers (Agency for Healthcare
Research and Quality 2000:1). This kind of employment history would have distinct salary implications and thus affect socioecononic status. Another study in the USA on the psychosocial implications of chronic renal failure showed that a decline in socio-econonic status could be associated with poorer health outcomes (Cukor et al. 2005).

\section{Loss of independence and spontaneous activities}

The patterns that emerged from the data analysis were twofold:

- confinement to the city of Windhoek

- $\quad$ long periods confined to a dialysis machine.

\section{Confinement to the city of Windhoek}

The availability of haemodialysis is limited in Namibia. In 2009 only the city of Windhoek and the towns of Walvis Bay and Ongwedhiwa offered facilities for dialysis, thus anyone requiring haemodialysis for chronic renal failure could be assisted only in these three places. This, therefore, placed restrictions on casual movements (especially those during holidays), as well as on the availability of employment opportunities and this aspect was echoed by a number of respondents. One participant commented:

'... since I have been placed on this treatment, I haven't left Windhoek, and I have problems. My family stays in [name of town omitted for the purpose of anonymity] and I could not have determined if there is a machine available there ...'

A similar observation was made by another patient:

'...if you want to go and visit someone, you cannot do that. That is the most difficult thing'.

Confinement to Windhoek not only impacted on their lives, but also on those of their family members, as evidenced by a respondent's sentiment: '... cannot take the family to Swakopmund' (a popular holiday town on the west coast of Namibia).

In a study carried out in Scandinavia, patients with chronic renal failure had similar experiences, which were categorised by the researchers as a feeling that life is restricted (Hagren et al. 2005).

Any travelling, should it occur, could not exceed two days, as many of the participants had to be dialysed every second day, or at least three times a week. If they should want to leave Windhoek for periods of longer than two to three days, but still remain in Namibia, they had to be close to either Walvis Bay or Ongwedhiwa - the only other centres where dialysis facilities are available. Even then, they needed to obtain permission and plan accordingly.

If any of the patients intended to leave Namibia for a visit to South Africa, and required dialysis during this visit, their planning had to be even more comprehensive. Documents recording the relevant medical history, as well as clarifications of the way payment would be made, are just some of the aspects that required consideration. Once there, new stresses emerged, as one participant explained:

'You do not know the place. You have to look for this hospital. When you get there, then you have to go here and then there. Some will help you, others know that they have to help you, but they are not eager to help you'.

In a related study on the quality of life of patients with chronic renal failure, Maxwell and Fitzpatrick (1998:182) described similar experiences in their patients, and refer to them as a loss of control over their own destiny.

Long periods confined to the dialysis machine

The majority of the participants were dialysed three times a week for at least $4 \mathrm{~h}$ at a time, giving a total time of at least $12 \mathrm{~h}$ per week spent connected to a dialysis machine. Given the fact that the patients needed to be available for about 30 min before the time for the necessary pre-dialysis preparations, such as the taking of vital signs and being connected to the machine, another 90 min could be added per week. In addition, many participants 
relied on taxis to reach the facility, which also added to the time devoted to dialysis. One patient related that:

'... it was terrible in that I suddenly had to give up on life and sit here for four hours a day'.

Similar experiences of chronic renal failure patients were described by Hagren et al. (2005:294-300), who referred to this as struggling with time-consuming care.

An emotionally laden description was given by another participant:

'... and then, if you have to go and lie down on a place and wait for this dirty job to be completed ... won't workout [sic]'.

These experiences of the participants are echoed by Hagen et al.'s Scandinavian study, which described the experience as dialysis treatment that encroaches on time and space (Hagren et al. 2005).

\section{Strain on relationships}

The relationships in this study pertain to the participants' family members, friends and work situation.

The patterns that formed the basis for causing strain in relationships were:

- $\quad$ altered family dynamics

- changed dynamics in social relations with friends

- work-related stress.

\section{Altered family dynamics}

The family is usually the first resource that participants will turn to when experiencing problems. The family circle is where strength and support are obtained, but it could also be the place where new stress and/or guilt is added.

In some instances, family members, in their efforts to be supportive, displayed patronising behaviour and reassurance from them sometimes downplayed the gravity of the situation. This may not have been comfortable for all the participants, as is evident from the following quote:

'They do not know what they can offer me and they are careful ... and ... uh ... it is simply just an uncomfortable situation. [I] cannot communicate with the family like before, and there is always ... in the way and everyone pitying [me] and "shame this, shame that ...'.

The same participant continued:

'They would like to support [encourage] me and all that, but I say no, it tires me.'

This contributes to a change in family dynamics, as observed by another participant

'... the family, even the children, the wife - ... they are no longer the same'.

In some instances, family activities had to be curtailed. One couple enjoyed outdoor activities, particularly the male partner, but the female partner developed chronic renal failure and described her experience as follows:

'... both of us liked going camping and suddenly I had to tell him [her husband] I cannot get off the bed. So - it touched our lives tremendously because suddenly we could not do anything ... we could do less, because he always had to be there ... had to be there [sic]'.

She added, emotionally:

'... he ... suddenly we could not do stuff together and the sacrifice was just too much for him. So, yes, I felt in the way'.

These experiences, as described by the participants, appear to indicate the existence of stressors or disturbances in family dynamics. A stressor is a demand placed on the family that has the potential to produce changes in the family system (Hanson, Gedaly-Duff \& Kaakinen 2005:83). In a study dealing with patients with chronic renal failure in the USA, it was found that disturbances in family dynamics are associated with poorer health outcomes (Cukor et al. 2005).

\section{Changed dynamics in social relations with friends}

Mention was also made of strain outside of the family context, in interactions with friends. Friends belong to a 'group', more specifically a primary group, which has the purpose of affiliation, meaning to fulfil the need for support and interpersonal contact (Swartz, De la Rey \& Duncan 2006:252). One participant commented that he was not being visited as often as before:

'Very difficult - they do not come any more, because they do not know how $[t o]$ "deal with me".

In some cases it appeared that the lifestyle changes required from the participants indirectly contributed to a breakdown in their social interactions with friends. Such an observation emerged from the following comment:

'With social gatherings I have to take my own, special diet foods. And my family also eats this diet. Our friends do not understand it. Many friends write you out of the company'.

Thus, the socio-econonic role or function of the primary group, as described by Swartz et al. (2006:252), appears not to have played a role in the experience of some participants.

In some instances the participants themselves contributed to the decline in visits and contact with friends because of their illness, as is evident from this remark:

'Normally ... [I] ... use to go out and hang out with friends and you know ... like, um ... watch soccer or do a lot of things, but nowadays you just stay at home, you don't really go out ... you have to save that energy for you know ...?'

In their comments on the quality of life of patients with chronic renal failure, Maxwell and Fitzpatrick (1998:182) also referred to the decrease in social activities experienced by patients with chronic renal failure.

\section{Work-related stress}

Some participants described stress that could be regarded as being directly related to their work. Some comments by the patients at first indicated complete acceptance by their employers; however, even if this were true, the participants might experience indirect strain. This was the case with one respondent, who had the advantage that his occupation was task-orientated and not necessarily office-bound. He explained this as follows:

'My boss understands. I have to do the bookkeeping and I do it also at home - It just has to be up to date. I am working from 8 to 11, and then I have to come for dialysis. After dialysis I am usually "finished" [exhausted], and therefore cannot return to my work'.

Although the participant experienced a sense of being accommodated by his employer, the fact remained that his work had to be completed - at home, if necessary. This implies that for dialysis patients, there might be work-related tasks to complete even at home.

Other participants described experiences which could be regarded as direct, work-related stress. One patient mentioned that her supervisor at work was not comfortable with her attending dialysis sessions three times a week:

'... and my supervisor at work they don't like it, they don't like it, they not supporting me'.

Not all the participants in the study who were still employed were office-bound, and some were expected to go on workrelated field trips and visits, often outside of Windhoek; as one respondent noted:

\section{'I am expected to go out on field trips, but I cannot do it'.} Another said:

'... and there are no machines ... these are the things I experience, yes, but I work such a distance from my home'. 
One student participant, whose studies could also be regarded as 'work', had this observation:

'The dialysis interfered with my studies. I have missed one examination - have to write immediately afterwards'.

This pattern of work-related stress could be related to ineffective role performance. Roles are sets of socially expected behaviour patterns that individuals fulfil throughout their lifespan (Urden et al. 2006:63). In this study, it is specific occupation, a tertiary role, that is affected. Due to their health challenges, the participants could not always demonstrate effective role performance, and thus experienced role stain and role stress, described in this study as work-related stress.

\section{Physiological changes and weakness}

The experience of significant physiological changes and weakness manifested as patterns of dramatic physiological changes and weakness.

\section{Dramatic physiological changes}

Dramatic physiological changes appeared to be experienced in a variety of ways, as maintained by a young participant:

'... and you won't be the same person, but in time you also change'.

Other specific physiological changes, or rather the realisation that a specific lifestyle is no longer possible, were also narrated by the participants. One of these 'realisations' regarded childbirth. One participant had had the dream of having another child:

'Yes, and [I] have two sons. I would have liked to have a girl, but now ...

Even the cessation of a function such as elimination is experienced as a loss. One male participant related how a simple activity like urinating is no longer the same:

'One thing that I miss, is to stand in the toilet and urinate, you know, that relaxing feeling'.

Another respondent expressed his experiences as follows:

'I am living a pitiful life. Look at my face. The body does not matter'.

Similar experiences were described by participants in Taiwan, where the researchers described these experiences as an impaired sense of self (Ko et al. 2007).

Such observations by participants indicate a disturbed body image. Urden et al. (2006:1169) state that when patients have a disturbed body, they express negative feelings about the body or a fear of rejection by others.

Another dramatic physiological change is the inability of patients' bodies to maintain a fluid balance, which necessitates a restriction of the intake of fluids, and requires discipline and willpower. The participants expressed their understanding of these restrictions, but it appeared to be internalised as demands:

"Just the knowledge that I "cannot" drink or eat in between [dialysis] because I will become swollen [sic]', and 'You "must not" eat a lot, you "must not" drink a lot; that is the thing'.

\section{Weakness}

Chronic renal failure as an affliction leads to a variety of different kinds of physical discomfort, quite often labelled as 'weakness'. Some of these experiences of weakness are due to the renal failure per se, and others are iatrogenic or treatment-induced (Urden et al. 2006). These experiences are not always predictable and can emerge unannounced. One patient commented:

'Sometimes I feel weak; I can't walk around. I just want to sit in the office'.

This discomfort (weakness) could also affect cognitive abilities, as is evident from this response:

'I had difficulty in concentrating ... after dialysis it felt as if my head was not with me [sic]'.
Such weakness is also described as tiredness by some patients:

'Some days I am too tired to clean the dishes,' or 'I can sit in front of the TV [after dialysis], but the next day I cannot recall what I had been watching'.

Some participants experience dizziness, a possible adverse effect of haemodialysis, which causes weakness. During a memberchecking activity, one respondent confirmed the dizziness episodes as being ongoing: 'Yes, daily here and there.' It appears from these observations that these participants' weaknesses are the result of iatrogenic factors.

In another study carried out in Taiwan, similar experiences were found, which were themed as physical fatigue (Lee et al. 2007), and the subthemes of this were categorised as habitual fatigue, fatigue due to uraemia and insufficient physical energy.

\section{LIMITATIONS OF THE STUDY}

A number of the participants were not fluent in either English or Afrikaans and the concept of 'quality' was not always immediately understandable. The researcher initiated neutral probing questions, but for most of the respondents it was necessary to provide the definition, as used in this study, of what is meant by the concept of 'quality'.

\section{RECOMMENDATIONS}

An optimum quality of life depends on the way the patients view their quality of life, to a certain extent. However, quality also depends on being able to afford basic amenities and to live a decent, predominantly independent life within a supporting social structure. The recommendation of this study is to extend and enhance the current social support system, which could include the following:

- A social worker could be appointed to assist patients who require chronic haemodialysis. This is also the view of the South African Renal Society (SARS), which states explicitly that the emotional and socio-econonic support of patients is integral to a holistic approach for the care given to patients on dialysis (South African Renal Society 2006:12).

- It is also recommended that the services of a clinical psychologist be made available. This is not unattainable for the participants in this study, because they are all being treated under the Fresenius Medical Care Group, which supports this idea. In its quality management checklists, one quality marker is listed as 'psycho-social support' (Fresenius Medical Care SA 2008: n.p.).

- Another recommendation is the strengthening of existing peer support between the participants. In providing more structure to this group, it might be possible to initiate fundraising opportunities. This could assist with financial support for nutritional supplements, medication and transport.

- A more structured peer support group could initiate an open day to invite employers and other relevant role players in the patients' professional and everyday activities to visit the dialysis unit. This could create a better understanding of the unique challenges faced by these patients.

\section{CONCLUSION}

The results of this study identified experiences (themes) of (1) financial constraints, (2) loss of independence, (3) strain on relationships and (4) significant physiological changes and discomfort. These experiences affect the patients' quality of life in various dimensions that cannot be described only from a physical perspective. Such themes therefore hint at the need for a more structured support system, not necessarily only financial, but also on a personal and advisory level. The recommendations are therefore based on an extension of the patients' current support systems. 


\section{ACKNOWLEDGEMENTS}

The researcher acknowledges the permission granted and support provided by Professor O.J. Oosthuizen.

\section{REFERENCES}

Agency for Healthcare Research and Quality, 2000, 'Determinants of disability in patients with chronic renal failure. Summary, evidence report/technology assessment, number 13', viewed 31 July 2009, from http://www.ahrq.gov/clinic/epcsums/ renalsum.htm

Arefzadeh, A., Lessanpezeshki, M. \& Seifi, S., 2009, 'The cost of hemodialysis in Iran', Saudi Journal of Kidney Disease and Transplants 20(2), 307-311, viewed July 2009, from http:/ / www.sjkdt.org/article.asp?issn

Copstead, L.C. \& Banasik, J.L., 2005, Pathophysiology, 3rd edn., Elsevier Saunders, St Louis.

Creswell, J.W., 1998, Research design: Qualitative and quantitative approaches, Sage, California.

Cukor, D., Cohen, S.D., Peterson, R.A. \& Kimmel, P.L., 2005, 'Psychosocial aspects of chronic disease: ESRD as a paradigmatic illness', Journal of the American Society of Nephrology 18, 3042-3055.

De Vos, A.S., Strydom, H., Fouché, C.B. \& Delport, C.L.S., 2003, Research at grass roots: For the social science and human service professions, 2nd edn., Van Schaik, Pretoria.

Fresenius Medical Care South Africa (Pty) Ltd., 2008, Induction and basic training for new FME employees, Service Department Training Room, Midrand.

Guyatt, G.H., Feeny, D.H. \& Patrick, D.L., 1993, 'Measuring health related quality of life', Annals of Internal Medicine 118(8), 622-629.

Hagren, B., Pettersen, I.M., Severinsson, E., Lützén, K. \& Clyne, N., 2005, 'Maintenance haemodialysis: Patients' experiences of their life situation', Journal of Clinical Nursing 14(3), 294-300.
Hanson, S.M.H., Gedaly-Duff, V. \& Kaakinen, J.R., 2005, Family health care nursing, 3rd edn., F.A. Davis, Philadelphia.

Hirth, R., 2009, 'In focus: Medical adherence', University of Michigan School of Public Health 24(1), 1, viewed 31 July 2009, from http:/ / www.sph.umich.edu/news_events/findings/ fallo8/inFOCUS/four.htm

Johnson, M. \& Maas, M., 1997, Nursing outcomes classification (NOC), Mosby, St Louis.

Ko, F.C., Lee, B.O. \& Shih, H.T., 2007, 'Subjective quality of life in patients undergoing long-term maintenance hemodialysis treatment: A qualitative perspective', Hu Li Za Zhi 54(1), 53-61 (original article in Chinese), viewed 31 July 2009, from http: / / www.ncbi.nlm.nih.gov/pubmed

Krefting, L., 1991, 'Rigor in qualitative research: Assessment of trustworthiness', American Journal of Occupational Therapy 45(3), 214-222.

Lee, B.O., Lin, C.C., Chaboyer, W., Chiang, C.L. \& Hung, C.C., 2007, 'The fatigue experience of haemodialysis patients in Taiwan', Journal of Clinical Nursing 16(2), 407-413.

Marieb, E.N. \& Hoehn, K., 2007, Human anatomy E physiology, Pearson Benjamin Cummings, Cape Town.

Maxwell, P. \& Fitzpatrick, R., 1998, 'End stage renal failure and assessment of health related quality of life', Quality Health Care 7, 182, viewed 31 October 2009, from qshc.bmj.com

'Science and development', The Southern Times, 21 September, 2008, p. 12.

South African Renal Society, 2006, SARS chronic dialysis guidelines, SARS, Cape Town.

Swartz, L., De La Rey, C. \& Duncan, N., 2006, Psychology. An introduction, Oxford University Press, Cape Town.

Urden, L.B., Stacy, K.M. \& Lough, M.E., 2006, Thelan's critical care nursing, 5th edn., Mosby, New York.

Verrelli, M., Chronic Renal Failure E Medicine from Web MD,

viewed 31 July 2009, from http://emedicine.medscape.com/ article/238798-overview

Wilson, H.S., 1989, Research in nursing, 2nd edn., AddisonWesley Publishing Company, California. 